\title{
High-Temperature Processing of Asbestos-Cement Roofing Material in a Plasma Reactor
}

\author{
Marián Lázár ${ }^{1 *}$, Mária Čarnogurská1, Tomáš Brestovičํㅜ, Natália Jasminská1, \\ Lubomíra Kmet'ová1, L’ubica Kapustová1, Tomáš Jezný ${ }^{2}$ \\ ${ }^{1}$ Faculty of Mechanical Engineering, Technical University of Košice, \\ Vysokoškolská 4, 04200 Košice, Slovakia \\ ${ }^{2}$ Faculty of Mechanical Engineering, Technical University of Košice, \\ Park Komenského 5, 04200 Košice, Slovakia
}

Received: 1 February 2016

Accepted: 29 April 2016

\begin{abstract}
This article describes a disposal method for two types of waste in a plasma reactor operating in a dependent connection, and the subsequent transformation of such waste into a vitrified glassy slag. Those two wastes are asbestos-cement roofing material and the fly ash from fluidized bed boilers. The first waste falls into the category of hazardous waste and the latter one in the category of so-called non-hazardous waste. In the Slovak Republic, both types of waste are currently disposed of through landfilling. Deficiencies related to landfilling waste are sorted through plasma melting technology in stationary and mobile modes. Achieving an inert product after the combined plasma melting of the mentioned waste is attained through the correct mix ratio and temperature. The high temperatures reached in the reaction chamber of the plasma reactor (up to $1,400^{\circ} \mathrm{C}$ ) guarantee the recrystallization of the chrysotile fibers represented in the asbestoscement roofing materials and their transformation into a glass matrix of the emerging products, creating vitrified slag. This product is predominantly a stable slag oxide (a mixture of $\mathrm{SiO}_{2}, \mathrm{CaO}, \mathrm{Al}_{2} \mathrm{O}_{3}$, and $\mathrm{MgO}$ ). It forms at the bottom of the reactor, a liquid phase that, following a regulated cooling phase, possesses properties suitable for further use in the production of insulation materials and ceramic products.
\end{abstract}

Keywords: hazardous waste, asbestos-cement roofing, plasma technology, manufacturing, vitrified slag

\section{Introduction}

Asbestos is one of a group of naturally occurring fibrous silicate minerals. It has been mainly and widely used in the production of thermal, acoustic insulation, and cement products. Globally, this special mineral has been used in more than 2,000 types of industrial applications.
In the Slovak Republic traces of asbestos-containing products can be found in the early $20^{\text {th }}$ century. In the 1970 's and 1980's the annual consumption of asbestos reached about 20,000 t per year. In $80 \%$ of the products, chrysotile was used, in $510 \%$ amosite, and in $10-15 \%$ crocidolite. The site of the micro-serpentine asbestos in the Slovak Republic was discovered in the deposit of Dobšiná. The produced short-waved asbestos was primarily used in the manufacture of asphalt roofing and in insulation covering [1]. 
By demonstrating the harmful effects of asbestos fibers on the human body and the subsequent adoption of the European Directive on the general prohibition in the use of all types of asbestos (EC, 1999), the manufacture of products containing asbestos has gradually stopped thanks to legislative measures [2- 4].

Through the aging of products containing asbestos, their mechanical derogation, and by wind erosion and other climatic factors, asbestos fibers are gradually released into the air. A comparison in the durability of various roofing types installed in roof systems is shown in (Fig. 1) [5]. In the Slovak Republic, waste containing asbestos fibers is disposed of through landfills only. Waste containing weakly bound asbestos fibers is, after being packed, subsequently disposed of in landfills for hazardous waste. Building materials containing asbestos fibers bound by a binder or packed in plastic can also be stored in landfills other than the ones for hazardous waste in line with Article 6 Letter c Paragraph iii of the Directive on landfills without testing [6]. These wastes may also be landfilled in a separate cell of a landfill for non-hazardous waste if the cell is sufficiently selfcontained [7].

If the landfills of hazardous waste are closed, the surface of the landfill has to be preserved in a way that its sealing force is at least the same as the landfill bottom. In the case of landfills of hazardous waste, the reclamation process creates a surface seal containing an artificial sealing layer and a drainage layer with a minimum thickness of $0.5 \mathrm{~m}$. Finally, the underground landfill is closed by a covering layer of minimum thickness $1 \mathrm{~m}$ [8]. By this method, the asbestos fibers - in the case of providing landfill integrity - are safely disposed of. Repeated release of fibers can occur if the sealing layers are disturbed, which cannot be $100 \%$ excluded.

Many studies about technologies for making asbestos inert using dry ash treatment include high-temperature melting and vitrification, microwave heating, hydrothermal conversion, and non-thermal technologies. The work of Gualtieri and Tartaglia [9] deals with the transformation of asbestos into a mixture of non-hazardous silicate phases throughout thermal treatment at $1,000-1,250^{\circ} \mathrm{C}$, and to a silicate glass at $t>1,250^{\circ} \mathrm{C}$. The resulting product of the process may be used in the production of traditional ceramic products. The use of microwave heating for the

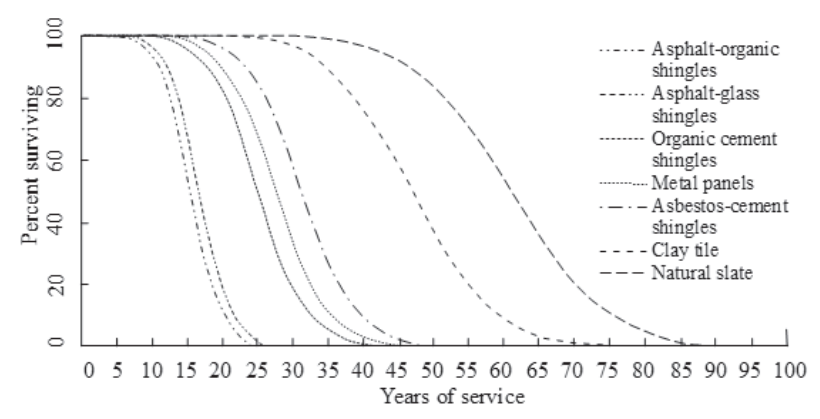

Fig. 1. Mean durability of steep-sloped roofing systems.

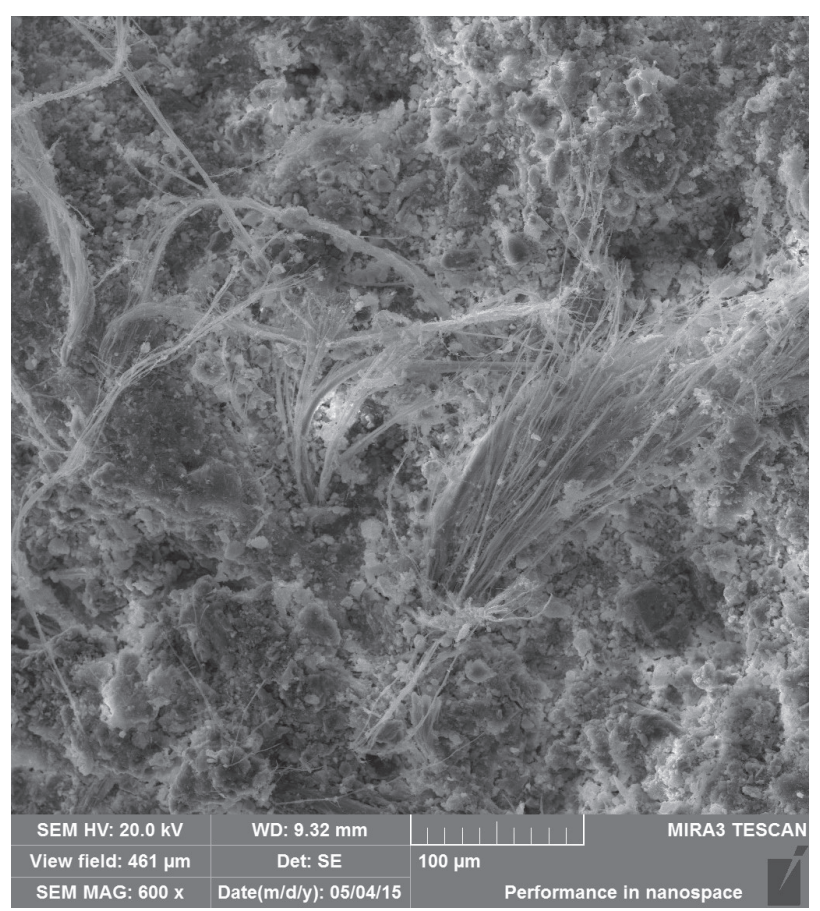

Fig. 2. Representative SEM image of chrysotile fibers detected on the surface of used asbestos-cement roofing.

disposal of asbestos-contaminated waste was addressed by the authors Averroes at el. [10]. By applying microwave plasma air, the plasma-treated microfiber particles were spheroidized and agglomerated. In the processing of asbestos roofing materials Colangelo et al. [11] used a high-energy ring mill for four hours. The very fine resultant powder obtained through the high-energy milling of asbestos-cement waste can be profitably recycled in the field of building materials.

Table 1. Chemical analysis of the asbestos-cement roofing material before the experiment.

\begin{tabular}{|c|c|}
\hline Component & (wt.\%) \\
\hline $\mathrm{SiO}_{2}$ & 21.30 \\
\hline $\mathrm{Al}_{2} \mathrm{O}_{3}$ & 5.09 \\
\hline $\mathrm{Fe}_{2} \mathrm{O}_{3}$ & 2.29 \\
\hline $\mathrm{CaO}$ & 42.50 \\
\hline $\mathrm{MgO}$ & 5.94 \\
\hline $\mathrm{MnO}$ & 0.15 \\
\hline $\mathrm{TiO}_{2}$ & 0.23 \\
\hline $\mathrm{Na}_{2} \mathrm{O}$ & $<0.20$ \\
\hline $\mathrm{K}_{2} \mathrm{O}$ & 0.25 \\
\hline $\mathrm{P}_{2} \mathrm{O}_{5}$ & $<0.01$ \\
\hline $\mathrm{SO}_{3}$ & 1.89 \\
\hline $\mathrm{LOI}$ & 20.20 \\
\hline
\end{tabular}


Table 2. Chemical analysis of fly ash originating from the fluidised bed boilers.

\begin{tabular}{|c|c|}
\hline Component & (wt.\%) \\
\hline $\mathrm{SiO}_{2}$ & 44.10 \\
\hline $\mathrm{Al}_{2} \mathrm{O}_{3}$ & 17.70 \\
\hline $\mathrm{Fe}_{2} \mathrm{O}_{3}$ & 7.28 \\
\hline $\mathrm{CaO}$ & 7.53 \\
\hline $\mathrm{MgO}$ & 1.66 \\
\hline $\mathrm{MnO}$ & 0.19 \\
\hline $\mathrm{TiO}_{2}$ & 0.71 \\
\hline $\mathrm{Na}_{2} \mathrm{O}$ & 0.40 \\
\hline $\mathrm{K}_{2} \mathrm{O}$ & 2.05 \\
\hline $\mathrm{P}_{2} \mathrm{O}_{5}$ & 0.30 \\
\hline $\mathrm{SO}_{3}$ & 2.04 \\
\hline LOI & 15.60 \\
\hline $\begin{array}{l}\text { The amount of metals set by } x \text {-ray fluorescence } \\
\text { spectral analysis }\end{array}$ & $\left(\mathrm{mg} \cdot \mathrm{kg}^{-1}\right)$ \\
\hline As & 8 \\
\hline $\mathrm{Ag}$ & $<2$ \\
\hline $\mathrm{Ba}$ & 1410 \\
\hline $\mathrm{Cd}$ & $<2$ \\
\hline $\mathrm{Cr}$ & 67 \\
\hline $\mathrm{Cu}$ & 38 \\
\hline $\mathrm{Hg}$ & $<2$ \\
\hline Mo & 3 \\
\hline $\mathrm{Ni}$ & 85 \\
\hline $\mathrm{Pb}$ & 39 \\
\hline $\mathrm{Sb}$ & $<2$ \\
\hline $\mathrm{Sr}$ & 355 \\
\hline $\mathrm{V}$ & 9 \\
\hline $\mathrm{Zn}$ & 82 \\
\hline $\mathrm{Zr}$ & 345 \\
\hline Elementary analysis & (wt.\%) \\
\hline $\mathrm{C}$ & 14.30 \\
\hline $\mathrm{H}$ & 0.18 \\
\hline $\mathrm{N}$ & 0.40 \\
\hline $\mathrm{S}_{\text {total }}$ & 0.92 \\
\hline
\end{tabular}

The primary objective of this paper is to describe the results of an experiment concerning plasma melting of asbestos cement roofing, which is a hazardous waste. A secondary goal is to use the fly ash from the fluidized bed boilers in the process of plasma melting, as yet another waste belonging to the non-hazardous waste group.

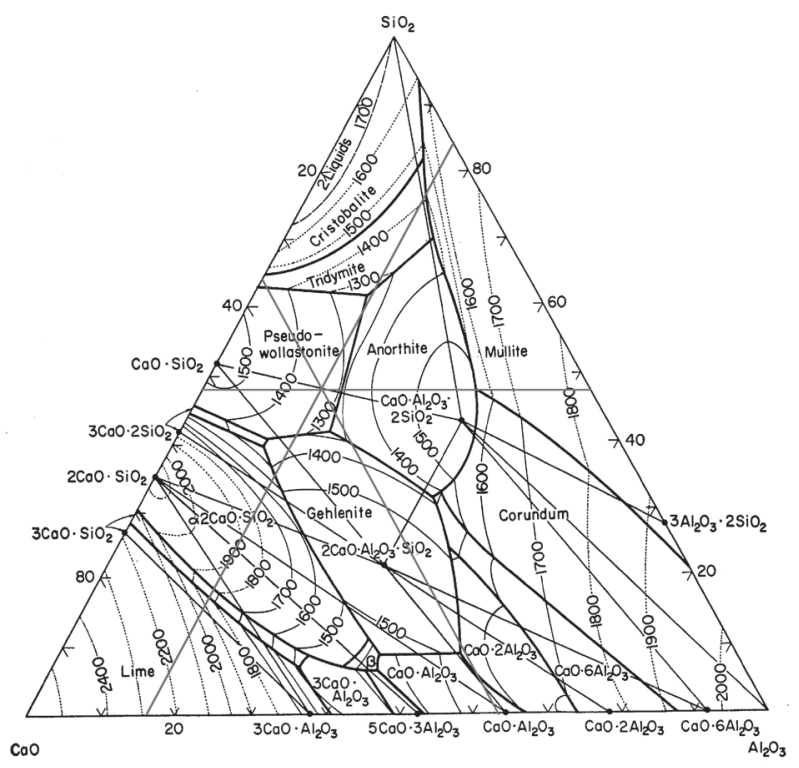

Fig. 3. Phase diagram of the $\mathrm{SiO}_{2}-\mathrm{CaO}-\mathrm{Al}_{2} \mathrm{O}_{3}$ system.

\section{Material and Methods}

Fig. 2 shows the SEM image of chrysotile fibers detected on the surface of used asbestos-cement roofing. This is the form in which the chrysotile is presented in the asbestos-cement roofing that is the subject of the experiment. Before the experiment the product was crushed, followed by milling to a size of less than $5 \mathrm{~mm}$. The experiment was performed on the laboratory device mentioned below. The chemical composition of a majority of asbestos-cement roofing components prior to melting is shown in (Table 1).

Considering the high content of the alkaline calcium oxide in the asbestos-cement roofing components (42.5 wt.\%), a suitable flux agent decreasing the melting temperature of the produced slag is $\mathrm{Na}_{2} \mathrm{O}, \mathrm{K}_{2} \mathrm{O}$, or acidic flux agent in the form of $\mathrm{SiO}_{2}$. In order to protect the environment, it was decided to replace the mentioned flux agents with another waste type - fly ash from fluid boilers. Fly ash from fluid hearths has features of an acidic flux agent (Table 2, contents of $\mathrm{SiO}_{2} 44.10$ wt.\%); moreover, this was the first time that fly ash as waste from thermal power plants has been used in a plasma-melting experiment.

By calculating the mixing ratio between the ground waste fraction of the asbestos-cement roofing and the fly ash from the fluidized bed boilers (using the phase diagram of the system of $\mathrm{SiO}_{2}-\mathrm{CaO}-\mathrm{Al}_{2} \mathrm{O}_{3}$ ), we were able to conclude that the suitable mixing ratio of the two types of waste, with the smelting temperature of the mixture in the range of $1,300-1,400^{\circ} \mathrm{C}$, is within the ratio range $0.6: 1$ to $1: 0.6$.

After the addition of the fly ash from fluid boilers to the crushed loading of asbestos-cement roofing material (waste mix ratio 1:1), the content of the created mixture is changed into approx. $25.0 \mathrm{hm} . \% \mathrm{CaO}, 32.7 \mathrm{hm} . \% \mathrm{SiO}_{2}$, and $11.4 \mathrm{hm} . \% \mathrm{Al}_{2} \mathrm{O}_{3}$. If the other mixture components are neglected and this mixture is applied into a ternary 
diagram (Fig. 3), the achieved melting temperature of the slag is approx. $1,330^{\circ} \mathrm{C}$. The presence of the oxides of $\mathrm{Fe}_{2} \mathrm{O}_{3}, \mathrm{Na}_{2} \mathrm{O}$, and $\mathrm{K}_{2} \mathrm{O}$ in the molten waste will further reduce the melting point.

During the melting process, the evaluation of the unused energy potential of the fly ash is achieved, where ash is found in the waste in the form of unused coal. Carbon represented in the ash will be used in a plasma melting process as a reducing agent and will contribute to the formation of carbon monoxide, which increases the calorific value of the synthesis gas generated as a by-product.

The smelting test of the mixture containing the asbestos-cement roofing materials and the ash was conducted in direct current (DC) of the plasma reactor. In the reactor, there is a plasma torch with hollow graphite electrodes that are connected in a dependent connection.

The technology is placed in a steel container that includes three main parts of the technology:

- Storage tank and screw-dosing device.

- A plasma reactor in a dependent connection.

- Cyclone separator and scrubber.

Mutual subsystems communication and a reliable operation of the technologies ensures PLC control. The technology as described above, which was proposed for the process of the generation of the plasma arc, mainly uses two kinds of inert gases: $\mathrm{N}_{2}$ or Ar. A broader description of the technique is mentioned by [12-15].

The smelting of the asbestos-cement roofing and the fly ash from the fluidized bed boilers, which are mixed in a ratio of 1:1, was performed under the reducing conditions. In the first stage of the experiment the optimum melting of the charge was achieved at a ratio of the operating time of dosing a screw feeder to the pause between individual stages of dosing at a ratio of 0.7:19.3 sec. The smelting of the $5.7 \mathrm{~kg}$ batch took place at a temperature range between $1,420-1,440^{\circ} \mathrm{C}$ for 28 minutes. The total amount of nitrogen introduced into the reacting chamber of the plasma reactor, as a sum of gas entering into the process of a discharge excitation $(72 \mathrm{~V}, 550 \mathrm{~A})$, and the gas serving for sealing purposes, is calculated at $4.81 \cdot \mathrm{min}^{-1}$ (determined as an average of values recorded by means of a gas flowmeter). After the tapping of the smelted mixture in Phase I, Phase II followed, during which the same mixture batch was smelted, weighing $3 \mathrm{~kg}$ and with boundary conditions corresponding to Phase I (Table 3). The difference between the two phases consists in the cooling process of vitrified slag. The setting of the sample of vitrified slag generated in the first phase of the experiment was performed by conduction and free convection and placed on concrete slabs at an ambient temperature of $15^{\circ} \mathrm{C}$. The second sample of vitrified slag at $\tau=30 \mathrm{~min}$ after its discharge into the cast iron ingot mold was submerged into the water bath at $15^{\circ} \mathrm{C}$.

\section{Results and Discussion}

The total mass of the vitrified slag obtained during the laboratory tests was around $6.903 \mathrm{~kg}(3.696 \mathrm{~kg}$ slag
Table 3. Operating parameters of the charge smelting.

\begin{tabular}{|c|c|c|}
\hline Operational parameters & $\begin{array}{c}\text { Phase } \\
\text { I. }\end{array}$ & $\begin{array}{c}\text { Phase } \\
\text { II. }\end{array}$ \\
\hline $\begin{array}{c}\text { Average temperature in the reaction } \\
\text { chamber }\left({ }^{\circ} \mathrm{C}\right)\end{array}$ & 1,430 & 1,470 \\
\hline Duration of the experiment $(\mathrm{min})$ & 28 & 15 \\
\hline Weight of the charge $(\mathrm{kg})$ & 5.7 & 3 \\
\hline Feeding speed $\left(\mathrm{kg} \cdot \mathrm{min}^{-1}\right)$ & 0.204 & 0.200 \\
\hline Nitrogen flow $\left(\mathrm{Nm}^{3} \cdot \mathrm{h}^{-1}\right)$ & 0.482 & 0.482 \\
\hline Total energy consumption $(\mathrm{kWh})$ & 18.8 & 10.3 \\
\hline $\begin{array}{c}\text { Energy consumption related to } 1 \mathrm{~kg} \\
\text { of the charge }\left(\mathrm{kWh} \cdot \mathrm{kg}^{-1}\right)\end{array}$ & 3.30 & 3.34 \\
\hline Synthesis gas production* $\left(\mathrm{m}^{3} \cdot \mathrm{kg}^{-1}\right)$ & 0.116 & 0.116 \\
\hline
\end{tabular}

from the first tapping (slag I), $2.047 \mathrm{~kg}$ samples from the second tapping (slag II), and $1.160 \mathrm{~kg}$ of slag collected from the bottom of the reactor below the tap-hole outlet). The results of the chemical analysis of the essential components of the matrix representation and the analysis of the proportion of metals in the slag (obtained using X-ray fluorescence spectrometric analysis) are in Table 4. The boundary conditions for the charge smelting, together with the measured and calculated values of specific energy consumption and the amount of the generated synthesis gas related to the $1 \mathrm{~kg}$ of the charge shows. The performance parameters of the reactor recorded during the smelting of the mixture of the asbestos-cement roofing and ash are stated in Fig. 4.

Throughout the experimental smelting of the mixture of the asbestos-cement roofing and the ash from the fluidised bed boilers a sample of gas mixture arising in the process showed the following composition: $\leq 0.001 \mathrm{CH}_{4}$, $20.24 \mathrm{H}_{2}, 3.29 \mathrm{O}_{2}, 26.9 \mathrm{~N}_{2}, 1.39 \mathrm{CO}_{2}, 44.3 \mathrm{CO}, 0.001$ $\mathrm{C}_{2} \mathrm{H}_{4}, \leq 0.001 \mathrm{C}_{2} \mathrm{H}_{6}, 0.002 \mathrm{C}_{2} \mathrm{H}_{2}$, and 0.004 sum of the C3-8 hydrocarbons.

After the experiment of the charge melting we obtained three final products: vitrified slag product, syngas, and light ash [16-18]. The unburnt part existing in the fly ash originated in the fluidized bed boilers and was used as an auxiliary flux to reduce the melting point of the

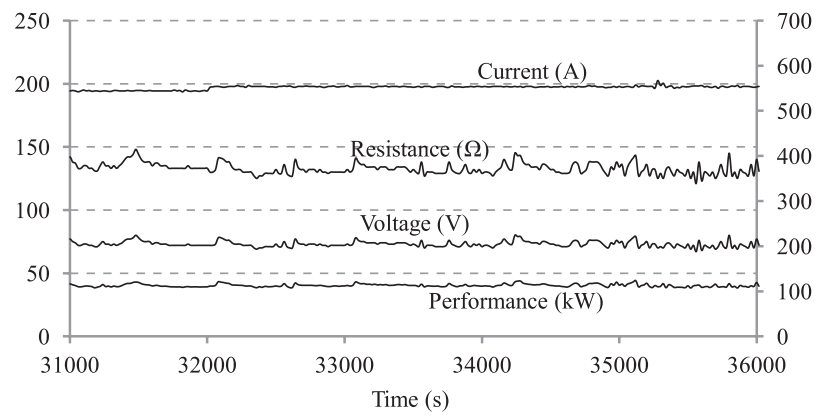

Fig. 4. Performance parameters of the reactor during smelting. 
asbestos-cement roofing as a reducing agent during the melting process. The resulting synthesis gas with a volume of $116 \mathrm{l} \cdot \mathrm{kg}^{-1}$ of charge, with a calorific value of $8.205 \mathrm{MJ} \cdot \mathrm{m}^{-3}$, allows further energy recovery. Before that, the gas must be cleaned in order to remove such undesirable constituents as sulfur dioxide [19]. The occurrence of sulfur in the ash (Table 2) is anticipated based on the presence of sulfates, which in a highly reducing atmosphere and at a high temperature are reduced and thermally decomposed according to the following equation:

$\mathrm{MeSO}_{4}(\mathrm{~s})+2 \mathrm{CO}(\mathrm{g}) \rightleftharpoons \mathrm{Me}(1, \mathrm{~g})+2 \mathrm{CO}_{2}(\mathrm{~g})+\mathrm{SO}_{2}(\mathrm{~g})$

...where $\mathrm{MeSO}_{4}$ are the sulphates, Me is a reduced metal, (s) is the solidus, ( $\mathrm{g}$ ) is gaseous, and ( $\mathrm{lg}$ ) is the designation for liquids and gasses.

The stability of metal oxides existing in the charge that contains two types of waste processed in a strongly reducing atmosphere and at a high temperature could be assessed based on the dependence of changes of Standard Gibbs Free Energy of the temperature. The change of the Standard Gibbs Free Energy for the formation of oxides and the comparison of X-ray fluorescent spectrometry analysis of the charge and the resulting vitrified slag (Table 4) are described in [12].

The slag-stable oxides $\mathrm{SiO}_{2}, \mathrm{Al}_{2} \mathrm{O}_{3}, \mathrm{CaO}$, and $\mathrm{MgO}$ forming the major part of the charge also represent the basis for the major target product obtained after the melting process of a mixture of asbestos-cement roofing and ash from the fluidised bed boilers. The specific weight of the solidified vitrified slag specified by the Archimedes method was 2,800 to $2,950 \mathrm{~kg} \cdot \mathrm{m}^{-3}$. Among other important parameters of the vitrified mixture of the asbestos roofing and the ash from the fluidised bed boilers are the volume and the mass reduction achieved during melting. The decrease in weight of the slag was set to $21.6 \mathrm{wt} . \%$. The value of the volume reduction is relatively high with a value of about 79 vol. $\%$.

Less stable oxides with a low oxygen affinity toward $\mathrm{Fe}, \mathrm{Cu}, \mathrm{Ni}$, and $\mathrm{Ag}$ (or the like, being in accordance with general chemical reactions (2) to (4)), are reduced and could form an independent metal phase in the reactor.

$$
\begin{aligned}
& \mathrm{MeO}(\mathrm{l})+\mathrm{C}(\mathrm{s}) \rightleftharpoons \mathrm{Me}(1, \mathrm{~g})+\mathrm{CO}(\mathrm{g}) \\
& \mathrm{MeO}(\mathrm{l})+\mathrm{CO}(\mathrm{g}) \rightleftharpoons \mathrm{Me}(1, \mathrm{~g})+\mathrm{CO}_{2}(\mathrm{~g})
\end{aligned}
$$

... where $\mathrm{MeO}$ means less stable metal oxides.

Between the carbon monoxide and the carbon oxide, the Bell-Boudouard reaction takes place:

$$
\mathrm{CO}_{2}(\mathrm{~g})+\mathrm{C}(\mathrm{s}) \rightleftharpoons 2 \mathrm{CO}(\mathrm{g})
$$

Metal oxides with a low boiling point and a high vapor

\begin{tabular}{|c|c|}
\hline Component & (wt.\%) \\
\hline $\mathrm{SiO}_{2}$ & 32.10 \\
\hline $\mathrm{Al}_{2} \mathrm{O}_{3}$ & 27.50 \\
\hline $\mathrm{Fe}_{2} \mathrm{O}_{3}$ & 0.31 \\
\hline $\mathrm{CaO}$ & 33.50 \\
\hline $\mathrm{MgO}$ & 4.33 \\
\hline $\mathrm{TiO}_{2}$ & 0.58 \\
\hline $\mathrm{MnO}$ & 0.04 \\
\hline $\mathrm{K}_{2} \mathrm{O}$ & 0.16 \\
\hline $\mathrm{Na}_{2} \mathrm{O}$ & 0.09 \\
\hline $\mathrm{P}_{2} \mathrm{O}_{5}$ & $<0.01$ \\
\hline $\begin{array}{l}\text { The amount of metals set by } x \text {-ray } \\
\text { fluorescence spectral analysis }\end{array}$ & $\left(\mathrm{mg} \cdot \mathrm{kg}^{1}\right)$ \\
\hline $\mathrm{V}$ & 11 \\
\hline $\mathrm{Cr}$ & 44 \\
\hline $\mathrm{Ni}$ & 6 \\
\hline $\mathrm{Cu}$ & 585 \\
\hline $\mathrm{Zn}$ & $<5$ \\
\hline As & $<2$ \\
\hline $\mathrm{Br}$ & $<10$ \\
\hline $\mathrm{Zr}$ & 827 \\
\hline $\mathrm{Nb}$ & 3 \\
\hline Mo & $<3$ \\
\hline $\mathrm{Ag}$ & $<2$ \\
\hline $\mathrm{Cd}$ & $<2$ \\
\hline $\mathrm{Sb}$ & $<2$ \\
\hline $\mathrm{Ba}$ & 3,651 \\
\hline $\mathrm{Hg}$ & $<2$ \\
\hline $\mathrm{Pb}$ & 6 \\
\hline Elementary analysis & (wt.\%) \\
\hline $\mathrm{C}$ & 0.23 \\
\hline $\mathrm{H}$ & 0.36 \\
\hline $\mathrm{N}$ & 0.16 \\
\hline $\mathrm{S}$ & 0.43 \\
\hline $\mathrm{Cl}$ & $<0.01$ \\
\hline
\end{tabular}
pressure (such as $\mathrm{Hg}, \mathrm{Cd}$, and $\mathrm{Pb}$ presented in the waste)
Table 4. Chemical analysis of the vitrified slag.

are largely evaporated into the synthesis gas, from which they are precipitated and collected as fly ash in the gascleaning device. A similar pattern occurs in the case of alkali metals $\mathrm{Na}$ and $\mathrm{K}$, oxides of which escape during the smelting process in a highly reducing atmosphere at a high temperature into synthesis gas. This fact confirms the low 
Table 5. Parameters characterizing the vitrified slag leachate.

\begin{tabular}{|c|c|c|}
\hline Parameters & $\begin{array}{l}\text { Vitrified slag } \\
\text { leachate } \\
\text { composition }\end{array}$ & $\begin{array}{c}\text { Method } \\
\text { of determination }\end{array}$ \\
\hline $\mathrm{pH}(1)$ & 7.0 & STN ISO 10523 \\
\hline As $\left(m g \cdot l^{-1}\right)$ & $<0.0275$ & STN EN ISO 15586 \\
\hline $\mathrm{Ba}\left(\mathrm{mg} \cdot \mathrm{l}^{-1}\right)$ & 0.024 & STN EN ISO 11885 \\
\hline $\mathrm{Cd}\left(\mathrm{mg} \cdot \mathrm{l}^{-1}\right)$ & $<0.00060$ & STN EN ISO 15586 \\
\hline $\mathrm{Cr}\left(\mathrm{mg} \cdot \mathrm{l}^{-1}\right)$ & $<0.005$ & STN EN ISO 11885 \\
\hline $\mathrm{Cu}\left(\mathrm{mg} \cdot \mathrm{l}^{-1}\right)$ & 0.0515 & STN EN ISO 11885 \\
\hline $\mathrm{Hg}\left(\mathrm{mg} \cdot \mathrm{l}^{-1}\right)$ & 0.001 & STN EN 1483 \\
\hline $\operatorname{Mo}\left(\mathrm{mg} \cdot 1^{-1}\right)$ & $<0.005$ & STN EN ISO 15586 \\
\hline $\mathrm{Ni}\left(\mathrm{mg} \cdot \mathrm{l}^{-1}\right)$ & $<0.005$ & STN EN ISO 11885 \\
\hline $\mathrm{Pb}\left(\mathrm{mg} \cdot \mathrm{l}^{-1}\right)$ & 0.0079 & STN EN ISO 15586 \\
\hline $\mathrm{Sb}\left(\mathrm{mg} \cdot \mathrm{l}^{-1}\right)$ & $<0.001$ & STN EN ISO 15586 \\
\hline $\mathrm{Se}\left(\mathrm{mg} \cdot \mathrm{l}^{-1}\right)$ & $<0.001$ & STN EN ISO 15586 \\
\hline $\mathrm{Zn}\left(\mathrm{mg} \cdot \mathrm{l}^{-1}\right)$ & 0.00266 & STN EN ISO 11885 \\
\hline Chlorides $\left(\mathrm{mg} \cdot \mathrm{l}^{-1}\right)$ & 1.1 & STN EN ISO 10304 \\
\hline Fluorides $\left(\mathrm{mg} \cdot \mathrm{l}^{-1}\right)$ & $<0.05$ & STN EN ISO 10304 \\
\hline Sulphate $\left(\mathrm{mg} \cdot \cdot^{-1}\right)$ & 7 & STN EN ISO 10304 \\
\hline Phenol index $\left(\mathrm{mg} \cdot \mathrm{l}^{-1}\right)$ & $<0.01$ & STN ISO 6439 \\
\hline $\mathrm{CRL}\left(\mathrm{mg} \cdot \mathrm{l}^{-1}\right)$ & 105 & STN 757373 \\
\hline
\end{tabular}

percentage quantity of alkali metal oxides in the samples taken from the vitrified slag.

The asbestos fibers existing in the form of chrysotile in the asbestos-cement products go through various phases of recrystallization due to the influence of high-temperature processing.

Further heating occurs due to the chemical reactions taking place in the smelt at temperatures that are - at the point of arc discharge - significantly higher than the smelt temperature at the bottom of the reactor, where there is a degradation of fibers. This is also confirmed by analysis (electron probe micro analyzer, CAMECA SX100) that has not detected the presence of chrysotile fibers in the vitrified slag. Thus they were dissolved and incorporated inside the glassy phase or converted in high-temperature (not hazardous) silicates.

After the high-temperature waste treatment it is important to recognise the quality of the product and its environmental impact. The impact assessment of the vitrified slag on the environment was performed by analysing the leachability of the slag in an aqueous solution (Table 5) as well as the eco-toxicity. Leachability of the slag in an aqueous solution that was performed under the regulation of the Ministry of the Environment of Slovak Republic No. 372/2015 Coll. by taking into account the limit indicators listed in regulation 2003/33/EC. Slag obtained from the experiment belongs to the category of inert materials and does not have the properties harmful to the environment and wildlife. On a sample of vitrified slag tests of acute toxicity on fish (Poecilia reticulata) were performed along with daphnia (Daphnia magna), inhibition of growth of green alga (Desmodesmus subspicatus), and a test of the inhibition of root growth - higher crop plant - white mustard (Sinapis $a l b a)$ in line with methodology STN 83 8303. Results of the ecotoxicology tests show negative values on all tested organisms: fish, daphnia, green alga, and mustard roots. Based on this assessment and leachability of the slag we can state that the vitrified slag has no negative impact on the environment.

After the smelting process of the asbestos-cement coverings, together with the fly ash from the fluidised bed boilers, we obtained the main product in the form of vitrified slag. The slag composition can be modified by adding a flux in such a way that the slag may also be further used in, e.g., construction [13]. According to the analyses performed so far, for the material recovery of the obtained slag, a domain of mineral wool production and foam glass is proposed.

\section{Conclusions}

The hazardous nature of asbestos material lies in the release of respirable asbestos fibers from waste materials into the environment. The inhalation of these carcinogenic substances and their deep penetration into the lungs represents a serious risk of disease. This risk increases with the concentration of fibers in space and time of its impingement on the human body [20].

The disposal of asbestos-cement products as a hazardous waste in the Slovak Republic, as well as worldwide, is currently a serious problem. The categorised waste in waste group number 170605 is mostly disposed of through landfilling. Only a negligible amount of such waste is recovered. From an environmental and health point of view asbestos-contaminated waste represents a continued risk that consists of the release of inhalable substances into the atmosphere. The plasma smelting and the gasification of waste as an innovative and currently underused technology in waste management represents one possible alternative for the effective disposal of asbestos-cement products, while offering the opportunity to use all the products resulting from its disposal. The main product of the thermal processing (vitrified slag), depending on its final form, composition, and structure (modifiable by changing the boundary conditions of the heat and the addition of additives), has property exploitable for different sectors of the construction industry.

\section{Acknowledgements}

This article was created with the support of the Ministry of Education for the EU Structural Funds Operational Research and Development Program, project 
Nos. p. ITMS 26220220044, KEGA 003TUKE-4/2016 and VEGA 1/0004/14.

\section{References}

1. KMEŤOVÁ L'. Disposal of asbestos. TechCON. 11, 7, 2015.

2. BOURGAULT M. H., GAGNÉ M., VALCKE M. Lung cancer and mesothelioma risk assessment for a population environmentally exposed to asbestos. Inter. J. Hyg. Environ. Health. 217 (2-3), 340, 2014.

3. FISCHER M., GUNTHER K., MULLER K. M. Fibre-years, pulmonary asbestos burden and asbestosis. Inter. J. Hyg. Environ. Health. 205 (3), 245, 2002.

4. WACHOWSKI L., DOMKA L. Sources and Effects of Asbestos and Other Mineral Fibres Present in Ambient Air. Pol. J. Environ. Stud. 9 (6), 443, 2000.

5. MÖLlER M., HEDRICK J. L., DEGÉE P., DUBOIS P. Roofing Encyklopedia of Materials - Science and Technology, Pergamon, 2001.

6. Council Decision 2003/33/EC. Establishing criteria and procedures for the acceptance of waste at landfills pursuant to Article 16 of and Annex II to Directive 1999/31/EC. 2003.

7. ADAMCOVÁ D., VAVERKOVÁ M.D., STEJSKAL B., BŘOUŠKOVÁ E. Household Solid Waste Composition Focusing on Hazardous Waste, Pol. J. Environ. Stud. 25 (2), 487, 2016.

8. Regulation 372/2015. Regulation of the Ministry of Environment of Slovak Republic about waste landfilling and temporary storage of metallic mercury. 2015.

9. GUALTIERI A.F., TARTAGLIA A. Thermal decomposition of asbestos and recycling in traditional ceramics. J. Eur. Ceram. Soc. 20, 1409, 2000.

10. AVERROES A., SEKIGUCHI K., SAKAMOTO K. Treatment of airborne asbestos and asbestos-like microfiber par- ticles using atmospheric microwave air plasma. J. Hazard. Mater. 195, 405, 2011.

11. COLANGELO R., CIOFFI M., LAVORGNA L., VERDOLOTTI L., STEFANO D.E. Treatment and recycling of asbestos-cement containing waste. J. Hazard. Mater. 195, 391, 2011

12. ČARNOGURSKÁ M., LÁZÁR M. Plasma technology for waste treatment and recovery, Košice, 2013.

13. LÁZÁR M., JASMINSKÁ N., LENGYELOVÁ M. Experiment of gasification of the synthetically mixed sample of waste in nitrogen atmosphere. Acta Mech. Automat. 7, 34, 2013.

14. JEZNÝ T., JASMINSKÁ N., HORBAJ P. Plasma technology. EKO - Ecol. Soc. 21, 18, 2010.

15. LÁZÁR M., BRESTOVIČ T., ČARNOGURSKÁ M., JASMINSKÁ N. Determination of boundary conditions and optimalisation of the graphite electrode cooling circuit. Appied Mech. Mat. 816, 88, 2015.

16. LÁZÁR M., LENGYELOVÁ M., IMRIŠ I. Vitrification of Fly-Ash from Combustion of Municipal Waste in a Plasma Reactor. Chem. listy. 108, 148, 2014.

17. SZALATKIEWICZ J. Energy Recovery from Waste of Printed Circuit Boards in Plasmatron Plasma Reactor. Pol. J. Environ. Stud. 23 (1), 277, 2014.

18. BOROWSKI G. Using Vitrification for Sewage Sludge Combustion Ash Disposal. Pol. J. Environ. Stud. 24 (5), 1889, 2015.

19. NOSEK R., HOLUBČÍK, M., PAPUČÍK Š. Emission cont rols using different temperature of combustion air. Scien. Word J. 2014, 6, 2014.

20. GOMEZ E., AMUTHA RANI D., CHEESEMAN C. R., DEEGAN D., WISE M., BOCCACCINI A. R. Thermal plasma technology for the treatment of waste. J. Hazard. Mater. 161, 614, 2009. 